\title{
MuseERne OG VERDENSORDENEN KUNSTKAMMERETS OPSTÅEN OG GRUNDIDÉ
}

\author{
Mogens Bencard
}

Der findes vel ingen Dansker, som ikke har fäet sit forhold til Kunstkammeret, defineret af H.C.Andersen: "- og Arten kom paa Konstkamret, hvor den endnu er at see, dersom Ingen har taget den."

I denne lille satning indbyggede Andersen to erindringer om Kunstkammeret. Den ene, at det var et sted, hvor man henlagde pudsige ting. Som museumsmand kan man se protokolindførslen for sig: "En art, der siges at have gjort en virkelig prinsesse gul og grøn over hele kroppen, til trods for, at hun lå oven på 20 madrasser og 20 edderdunsdyner. "Og den anden: at det var et sted, hvor man ikke havde helt styr på sin samling. Den smertelige erindring om det nationale tab af Guldhornene $e^{t}$ levede endnu, men kunne dog, en menneskegeneration senere, behandles spogefuldt.

Andersen udgav sit eventyr i 1835, ca. 10 år efter at Kunstkammeret var blevet opløst og erstattet af et moderne, videnskabeligt museumsvesen. Med fremskridtets overlegenhedsfolelse kunne man tillade sig at pege fingre af det foraldede. Og det er der jo intet nyt $i$.

Trods megen litteratur om emnet Kunstkammer, både nationalt og internationalt, og trods en stærkt intensiveret forskning om emnet inden for de sidste 10-15 år, løber man fortsat, selv inden for fagkredse, ind i denne overbærenhed over for de gamle Kunstkamre som rene og skære raritetskabinetter, indsamlet uden systematik og idé. Det er min hensigt $\mathrm{i}$ det følgende at forsøge en placering af Kunstkammeret $\mathrm{i}$ sin egen tids forudsætninger og idealer. Lykkes det, vil man måske indse, at der ikke var større forskel mellem dette og det moderne museum.

At mennesker, ud fra individets lyst og interesse, til enhver tid har samlet, turde være så velkendt, at man her kan tillade sig at springe det over, for at gå direkte til vort emnes forudsætninger. De ligger i middelalderens kirkelige institutioner, datidens forsamlingshuse. I klostrenes biblioteker koncentreredes datidens forskning - ikke kun den teologiske, men også f. eks. den historiske. Egentlige genstandssamlinger fandtes dog sjældent hér, men i de store 
4 kirkers skatkamre. Her opbevaredes ikke kun de kostbareste af de hellige kar og af tekstiler til kirkeligt brug, men også ting, der ansås for at have undergørende virkning. I S. Denis uden for Paris f. eks. fandtes det enhjørningshorn, der blev taget frem med jævne mellemrum, for at helbrede ved sin iboende kraft. Det kan i dag beses i Cluny-museet i Paris. Andre naturalia, knogler af hvaler og mammut eller meteorsten fandt plads her, som vidnesbyrd om den rige og gådefulde natur - og naturligvis om Guds almagt. Individuelle genstandsgaver modtog kirken også i rigt mål, som takofre til giverens evige ihukommelse. Etnografica, f. eks. fra korstog, kunne på denne baggrund finde vej til kirkerne, både $\mathrm{i}$ form af våben og egentlige kunstgenstande, samt af kostbare orientalske tekstiler. At billedkunsten også var rigt repræsenteret skal kun nævnes for at fremhæve den lighed, der faktisk findes mellem den datidige kirke og et altomfattende museum. Forskellen ligger i det pædagogiske formål: i kirkerne fandtes det hele kunst, kunstindustri, naturalia, etnografica, m.v. - frem for alt for at fremme Gudsdyrkelsen.

Også middelalderens fyrster samlede, men vor viden herom er mere tilfældig. Berømt er dog den franske kongesøn, Jean de Berrys samling. Den kender vi grundigt, fordi den blev inventariseret i 1414, og fordi inventaret er bevaret. Foruden af bøger, var Duc de Berry en indædt storsamler af kunst, kunstindustri, og af medailler. Det fremgår til gengæld klart, at samlingen kun blev skabt til sin ejers tilfredsstillelse, den havde ingen overtoner af folkeopdragende art. Det var hertugens private skatkammer (som blev spredt umiddelbart efter hans død) på samme måde, som formentlig alle de middelalderlige fyrstesamlinger har været det.

Det turde være velbekendt, at Renaissancens italienske fyrster var store kunstmæcener. Hvad angår deres øvrige samlinger, vil litteraturen gerne lægge en manieristisk tankegang ind $\mathrm{i}$ dem, således at forstå, at de skal rumme et modsætningsforhold mellem samlingernes enkelte genstan$\mathrm{de}$ - fortrinsvis mellem den rå naturs uforarbejdede materialer og de samme materialer i kunstnerisk udformning. Påstanden kan være lidt vanskelig at bedømme, men er den rigtig, blev der bygget en vis systematisk tankegang ind i disse samlinger, og det er tilsyneladende noget nyt.

Et væsentligt tilskud til samlermaniens udvikling mod systematik kommer fra italiensk side, nemlig fra de private videnskabelige samlinger, der opstod i løbet af 1500 -årene. I hovedsagen var der tale om naturvidenskabsmænd, der samlede naturalia til at belyse deres forskellige specialer. Naturaliekabinetter er de blevet kaldt.

\section{DE FØRSTE KUNSTKAMRE}

Udviklingen mod det verdensoverskuende, encyclopædiske Kunstkammer tog dog for alvor fat omkring midten af det 16. århundrede i Tyskland. Et Kunstkammer blev for første gang omtalt i Wien i 1553, men der vides ikke meget om det, før det blev flyttet med Rudolf II til Prag. Rudolfs rige samlinger blev inventariseret 1607-11. Foruden kunstindustri - artificialia, som var skåle og opsatser udskåret i kostbare materialer, rummede samlingen naturalia og etnografica, med andre ord et bredt spektrum. Samlingerne var indlogeret i slottet i tæt tilknytning til Rudolfs gemakker, og det anses for tvivlsomt, om der 
overhovedet var adgang til dem for andre end en meget snæver kreds. Dertil var han selv for engageret i dem. Til gengæld synes indsamlingen af naturalia at have haft det formål at være en art depot, hvorfra der kunne udleveres råmaterialer til kunsthåndværkerne i Prags værksteder.

Kunstkammeret i Wien, der var indsamlet af Rudolfs fader, Ferdinand I, blev efter dennes død delt mellem hans fire sønner. Efter Rudolfs død forsøgte hans søn, Matthias at opnå sine medarvingers tilladelse til at holde samlingerne udelte, direkte tillagt Kronen. De kostbareste genstande - herunder Regalierne - skulle i henhold til hans idé forblive samlet, for at tjene Huset Habsburg til ære. Herved opstod Skatkammeret i Wien, som skiller sig ud fra Kunstkammeret ved at koncentrere sig om kostbarheder, altså ikke at være encyklopædisk. Ved andre hoffer hører man om sådanne udsøgte ting, der særligt var tillagt Kronen og fyrstens person, og det er måske dette, der skiller Skatkammeret fra Kunstkammeret.

Det andet Kunstkammer opstod i Dresden, sandsynligvis 1560. Det var indrettet $\mathrm{i}$ syv rum i residensslottet. Ved siden af Kunstkammeret oprettede eller udvidede kurfyrst August en mønt- og medaillesamling, et sølvkammer, et våbenkammer, et anatomikammer, et skatkammer og et bibliotek. Selve Kunstkammeret rummede ca. 10.000 genstande, videnskabelige instrumenter, kunst, og artificialia, men ingen etnografica. Interessant er den overvældende bestand af håndværkerredskaber, ialt godt 7.000. Samlingens historiker, Joachim Menzhausen, vil hævde, at disse - også - var beregnet til udlån blandt landets håndværkere. Har han ret, blev der hermed tilføjet museumstanken et folkeopdragende element.
Det næste Kunstkammer blev etableret i München, hvor det omtales første gang 1565. Hertug Albrecht V lod opføre en firfløjet bygning til sine samlinger ved siden af residensen, og det er således den første selvstændige museumsbygning. Den rummede fire hovedsamlinger: et Skatkammer, et Antikvarium for antik skulptur (vel mest en afstøbningssamling), et bibliotek og et Kunstkammer. Det sidste rummede malerkunst og grafik, artificialia af guld, sølv og halvædelsten, etnografica, mønter og medailler, men tilsyneladende ingen naturalia bortset fra jagttrofæer, der vel må ses som hertugens særlige interesseområde. Museet var allerede fra begyndelsen tilgængeligt for et udvalgt publikum og havde således en pædagogisk hensigt.

I München boede Samuel Quiccheberg, der i 1565 udgav det første museologiske skrift overhovedet, Inscriptiones vel tituli theatri amplissimi. Det sigter ikke specielt på hertug Albrecht og hans Kunstkammer, men er et teoretisk skrift, en ledetråd for enhver fyrste til indretning af omfattende samlinger. Det rummer et detailleret klassificeringssystem, men også en mangfoldighed af praktiske råd om en bevaringsmæssig og æstetisk passende præsentation af de forskellige objekter. Han finder det vigtigt at tilknytte værksteder og laboratorier for kunsthåndværksmæssig aktivitet - f. eks. til støbning og drejervirksomhed. Det sidste ansås endnu op i 1700-årene for en særlig vigtig aktivitet for medlemmer af fyrstehuse, kvindelige som mandlige. Desuden var et trykkeri og et bibliotek, samt et apotek (Quiccheberg var mediciner) nødvendigt.

Hans klassification af kunstkammeret skal kort omtales. I første klasse findes sakrale fremstillinger, grundlæggerens genealogi og portrætter af det herskende 
6 dynasti. Desuden topografiske fremstillinger af landet, af krigshandlinger og fester, af arkitektur, og af maskinmodeller. Et nationalhistorisk museum, kunne man kalde det. Næste klasse rummer skulptur og kunstindustri, samt evt. en kulturhistorisk oversigt over husgeråd, mål og vægt til forskellige tider og steder. Tredie klasse rummer naturalia - mennesker, dyr og planter, og fjerde videnskabelige instrumenter - et teknisk museum. Femte og sidste klasse rummer billedkunst og grafik.

Et "Teatrum" taler Quiccheberg om. Andre samtidige taler om et "Teatrum Mundi" - et Verdensteater. Tilsyneladende er der så megen nøgternhed i Quiccheberg, trods al teorien, at han indser, at museer $\mathrm{i}$ datiden kun kunne oprettes i denne skala i tilknytning til et fyrstehus, og det må være derfor, at han begynder med det nationale for derefter at begive sig ud i hele verden. Mærkeligt nok inddrager han dog ikke en verden uden for Europa, med mindre det er indlagt i den anden klasses kulturhistoriske oversigt. Hans beskrivelse forekommer dog mærkværdigt nærværende for et nutidigt museumsvæsen. Den væsentligste indsats ved hans skrift er dog den, at han satte museet, som begreb, ind $i$ en videnskabelig sammenhæng.

En anden tysk museumsteoretiker, Gabriel Kaltemarckt, skrev i 1587 en betænkning om "Hvordan et Kunstkammer kunne være indrettet". Der er dog en væsentlig forskel mellem de to skrifter. Hvor Quiccheberg er abstrakt, er Kaltenmarckt direkte, hvor den første er altomfattende, sigter den sidste primært på et kunstmuseum. Kaltemarckts betænkning er rettet til kurfyrst Christian I af Sachsen og afsluttes med ønsket om, at han må få stillingen som forvalter af det
Kunstkammer, han skitserer, et Kunstkammer, der er væsentligt forskelligt fra det Dresdner Kunstkammer, vi tidligere har hørt om.

Trods den åbenbare ensidighed beskriver Kaltenmarckt dog også, hvad der kan tilhøre et Kunstkammer. Først skulptur (herunder en afstøbningssamling af antikkens skulptur), dernæst malerkunst. Dernæst mærkværdige genstande fra nær og fjern af metal, sten, træ og urter, over og under jorden, fra $s ø$ og hav. Derefter genstande beregnet til spise- og drikkebrug, skabt af natur eller kunst, eller gjort af materialer herfra. Så takker, horn, kløer, fjer og skeletter, der stammer fra mærkværdige dyr, fisk og fugle. Hans fremstilling på dette område er ikke specielt systematisk. Derimod anfører han lange lister over kunstnere fra fortid og samtid, der bør være repræsenteret, og næsten som en nutidig kunstmuseumsmand anbefaler han, at kunsten holdes skarpt adskilt fra det øvrige.

Tidshistorisk mest interessant er hans forsvar for billedkunst som samlerobjekt. Han skrev til en lutheransk fyrste. Der var en billedfjendskhed af helt islamisk tilsnit indbygget $\mathrm{i}$ den tidlige lutheranske trosretning (fra Danmark kan til illustration nævnes de første lutheranske altertavler, hvorpå alle billeder var erstattet af ord), og i øvrigt endnu mere i de andre reformerte bevægelser. Hans argument er, at billedkunst kun bliver forkert, hvis man som katolikkerne tilbeder billederne.

Et tredie stort og tidligt Kunstkammer var ærkehertug Ferdinands på slottet Ambrass ved Innsbruck. Ferdinand, der var bror til Rudolf II og statholder i Tyrol, lod i 1573 opføre et firfløjet anlæg, der lå nedenfor hovedslottet. De tre fløje var viet til Ferdinands specielle interesse, våben, 
den fjerde til Kunstkammeret. Et særligt "Türkenkammer" rummede etnografica. Den øvrige samling bestod af billedkunst og grafik, artificialia (naturens materialer i kunstnerisk bearbejdet form), scientifica, mirabilia (f. eks. spillekort til giganter og dværge, portrætter af krøblinge og defor$\mathrm{me})$, en mindre samling antikker, en møntsamling og et bibliotek.

Samlingerne blev senere overført til Wien, men da slottet blev liggende med kunstkammersalene og deres indretning urørt, har man i de senere år retableret dette Kunstkammer, således at det er muligt at få et indtryk af, hvordan et sådant så ud. Vi behøver derfor ikke kun skriftlige kilder for at indse, hvorledes det ideelle Kunstkammer var opbygget, og hvad det bør rumme for at opfylde de betingelser, 1500-årene havde udarbejdet. Den basale idé var, at det skulle være et mikrokosmos af det samlede verdensbillede. Under et tag skulle man kunne studere det makrokosmos, som opdagelsesrejserne havde udvidet, primært til gavn for pengepungen, men også for en forskningsmæssig nysgerrighed. Kunstkammeret var ligesom de xldre samlinger skabt til fyrstens og landets ære, det nye var, at de ud over dette også var beregnet til udvidelse af ånd og erkendelse, for fyrsten, men også for en begrænset, ganske vist - del af hans folk. Her kunne man undre sig over naturens mangfoldighed og over menneskelig snilde, både inden for kunst og teknik. Til syvende og sidst kunne man, hvis man havde den tilbøjelighed, også her falde i forundring over Guds storhed.

Jeg skal ikke her nævne flere af de tyske Kunstkamre, kun anføre, at de fleste tyske fyrster opbyggede sådanne samlinger. Grundholdningen kunne variere, men alle skulle de fastholde den oplevelse, at hele verden var inden for rækkevidde.

England fik aldrig et kongeligt Kunstkammer, omend en privatsamling blev til The Ashmolean Museum i Oxford. Det var dog en englænder, filosoffen Francis Bacon, der i 1594 nedskrev sin forestilling om et Kunstkammer, mere altomfattende end noget andet:

"Først skal man samle et fuldendt og fuldstændigt bibliotek, med alt, hvad mennesket i sin snilde har skrevet. Dernæst en stor og vidunderlig have, med alle planter, der gror under forskellige klimatiske forhold og i forskellig jord. Derudenom skal bygges rum til alle sjældne dyr og fugle, og to nærliggende søer, den ene med salt- den anden med ferskvand for en lignende variation af fisk. Og således har man i lille skala en model af hele naturen. Det tredie skal være en passende stort kabinet, der skal rumme alt, hvad menneskets hånd har skabt ved udsøgt kunst eller maskine. Alt enestående, skabt ved tilfældigheder eller tingenes sammenblanding, og alt, som ved naturens luner er gjort livagtigt. Det fjerde skal være et tankens stille sted, således udstyret med maskiner, instrumenter, ovne og beholdere, at det kan være et palads, hvor man kan finde de vises sten." Med hans egne ord: "-- such a still-house, so furnished with mills, instruments, furnaces, and vessels as may be a palace fit for a philosopher's stone."

Til allersidst $\mathrm{i}$ denne oversigt over den internationale udvikling skal nævnes det Kunstkammer, som Peter d. Store i 1714 etablerede $\mathrm{i}$ en selvstændig bygning i $\mathrm{S}$. Petersborg. I 1708 havde Leibnitz skrevet således til zaren: Hvad angår museet og Kunstkammeret er det af største vigtighed, 
8 at de ikke kun rummer genstande af almindelig mærkværdighed, de skal også være steder for perfektion af kunst og videnskab." Den tanke greb Peter, den store folkelige og brutale pædagog. "Jeg ønsker, at Folket her skal se og lære”, skrev han.

\section{DET DANSKE KUNSTKAMMER}

Det har tidligere været nævnt, at drejerkunsten blev dyrket af fyrstefamilierne. Man anså den blandt andet for en god måde at lære dem at værdsætte godt håndværk. I det følgende, hvor vi skal beskæftige os med udviklingen i Danmark, vil det være naturligt, som Bering Liisberg har gjort det i sin bog om Kunstkam-meret, at begynde med Drejerkamrene. På Kronborg omtales dette værelse, der lå op til kongens sengekammer, i 1568 som et drejer- eller "Wunderkammer", men desværre vides der intet om, hvad Frederik 2. opbevarede her. Allerede Christian 3. havde et drejerkammer og sin private "Svarver", der var en højt betroet mand. Vi finder drejerkamre og lærere i den ædle kunst i tilknytning til samtlige generationer af kongefamilien. Den sidste lærer var Lorenz Spengler, der også var Kunstkammer-forvalter, og med ham er vi oppe $\mathrm{i}$ midten af 1700-årene. Det danske Kunstkammer er dog i forhold til det øvrige Europa en sen forteelse. Det blev først etableret ca. 1650 på Københavns Slot af Frederik 3.

Christian 4. synes ikke at have interesseret sig for Kunstkammer-begrebet, eller at have haft forståelse for dets nationale prestige og uddannelsesmulighed, til trods for, at begge dele lå ham stærkt på sinde. Han var ikke blottet for samlerlyst og manglede ikke interesse for videnskaberne, og man kan $\mathrm{i}$ hans omgivelser finde mange gen- stande, der naturligt ville have hørt hjemme på Kunstkamre af den type, som hans samtidige tyske slægtninge satte så højt. Måske skyldes det, at han var for meget af en praktisk mand til at tænke i de teoretiske baner, som en etablering af et Kunstkammer kræver. Han nøjedes med at være en samler af den gamle slags.

Det var sønnen, den ofte oversete tronfølger Prins Christian, der var familiens kunstsamler. På lysthuset Sparepenge ved Frederiksborg fandtes et rum med betegnelsen Kunstkammeret. Vi kender desværre ikke indholdet, men samlingen synes at have tilhørt prinsen. På Nykøbing Slot på Falster holdt han sammen med prinsesse Magdalene Sibylle, der var født i Dresden, et hof, hvor man dyrkede kunsten i alle dens aspekter. Det er sikkert karakteristisk for situationen, at Christian 4., da han i Glückstadt i 1639 fik overrakt det første guldhorn, på stedet overlod det til sønnen med en bemærkning om, at denne kunne lade gøre et guldbæger deraf til minde om fundet og Landets store fortid. Prinsen lod det dog restaurere og forsyne med en bundprop, så udsøgte fremmede kunne drikke deraf.

En sådan udsøgt var Ole Worm, der i sine breve fortæller om mødet med hornet, hvilket førte til hans berømte guldhornsbog. Man kan også af brevene konstatere prinsens og prinsessens levende interesse for hans videnskabelige arbejde. Prinsessen udbad sig hurtigt et eksemplar af bogen for at kunne sende den til søsteren og svogeren på Gottorp. De var begge storsamlere, hvorfor det prægtige guldhorn må have vakt deres interesse - og måske også deres misundelse. Datidens samlere har næppe haft instinkter, der var væsentligt forskellige fra nutidens. 


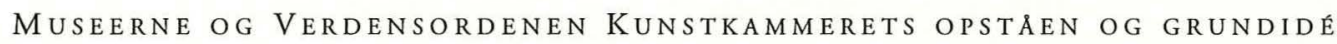

Prinsen døde som bekendt før faderen, som derefter over for prinsessen erklærede visse ejendele for umistelige for Kronen, deriblandt netop guldhornet. Hun kunne dog få lov til at beholde tingene hos sig til $\sin \mathrm{d} ø \mathrm{~d}$, eller indtil hun indgik et nyt ægteskab. Inden hun tog til Sachsen for at gifte sig påny, lod hun gøre sig den kopi af guldhornet, der findes bevaret i Dresden. Hun demonstrerede dermed sin samlerinteresse. Kongens erklæring skal formentlig ses som et eksempel på den Skatkammer-tanke, vi har mødt tidligere.

Som nævnt, blev det den næstældste søn, Frederik 3., der etablerede det danske Kunstkammer. I begyndelsen samlede han interessante genstande i sit drejerkammer, der også var hans sengekammer, på Københavns Slot. Det blev hurtigt udvidet til en række rum i de øvre etager i slottets kongefløj, tilsyneladende beliggende på samme måde som Rudolfs i Prag og med samme tætte tilknytning til kongens person. Der er mange eksempler på, hvordan Frederik ved $\mathrm{k} ø \mathrm{~b}$ og bestillinger udvidede sin samling. 1652 fik hans rustmester og kunstkammerforvalter Jacob Jensen Nordmand således udleveret elfenben til at udarbejde den store model af fregatten Norske Løve, som blev færdig to år senere. Samme år sendte kurfyrsten i Berlin ham på kongens opfordring - en lysekrone af Rav. Både skibet og kronen findes i dag på Rosenborg. Men det er kun fă af mange vidnesbyrd om kongens iver for at udvide sit Kunstkammer. I sin bog om Kunstkammeret har Bering Liisberg publiceret en række af disse indkøb.

1654 opnåede Frederik 3. den største samlede udvidelse. Det år døde nemlig Ole Worm, den internationalt berømte naturvidenskabsmand og oldforsker, og det lyk kedes kongen at overtale hans arvinger til at lade Worms store samling overgå til ham. Det var en internationalt kendt samling, kongen overtog. Worm havde allerede i 1642 og 1645 udgivet et par mindre kataloger, og året efter overtagelsen kunne det store katalog, som Worm havde efterladt sig, se dagens lys. Kataloget var rigt illustreret, ikke kun med det berømte billede af interiøret, men også af samlingens enkelte elementer. Samlingen er i ikke ringe grad et naturaliekabinet, men den indeholder dog et betydeligt element af artificialia og antikker, bl. a. fra den nordiske oldtid. Den præges således af det, der var Worms videnskabelige interesser, og kan derfor sammenlignes med de tidligere nævnte italienske videnskabelige samlinger. Jeg skal ikke her gå i detailler med Worms samling, den er så fremragende publiceret og behandlet af H.D.Schepelern, kun anføre, at det i ikke ringe grad var denne, der ændrede Frederik 3.s Kunstkammer fra en gammel fyrstesamling til det virkeligt encyklopædiske Museum, som vi har set, var datidens ideal. På grund af Christian 4.s forsømmelse var det danske Kunstkammer en sildefødning blandt Kunstkamre, til gengæld fik det en flot start, dels på grund af sønnens forståelse for området, men sandelig også fordi en af Christians egne undersåtter havde sikret landet international anerkendelse også på museumsområdet.

De mange forøgelser skabte, som det er tilfældet for ethvert aktivt museum, hurtigt pladsproblemer, men Frederik 3. fik ikke muligheder for at gøre noget ved det før efter Svenskekrigene. Grundstenen til en ny bygning blev lagt i 1665 . Huset, der kom til at ligge, hvor Rigsarkivet er i dag, blev således $i$ lighed med, hvad vi har truf 


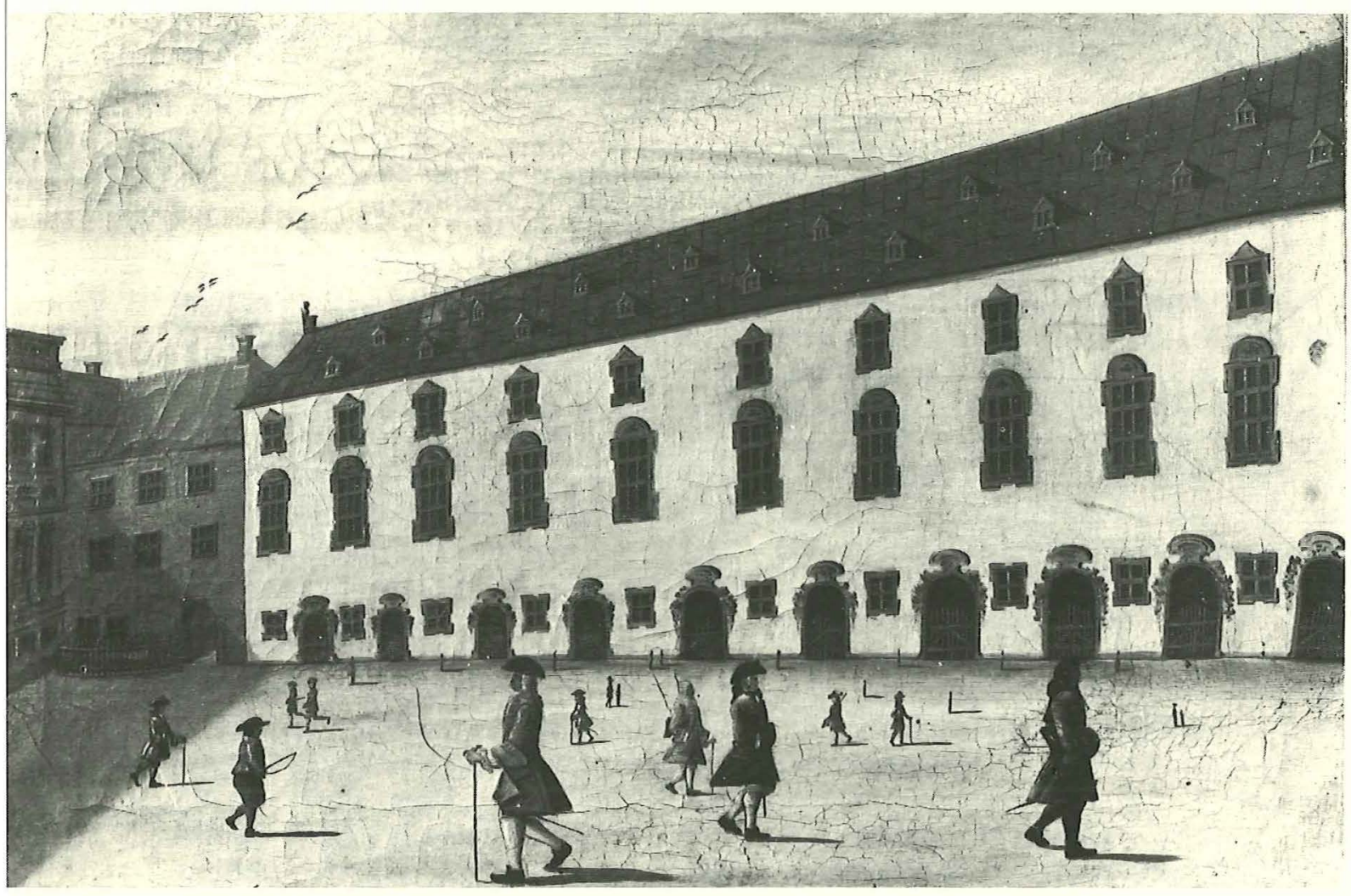

Kunstkammer og Kongeligt bibliotek omkring midten af 18. arrhundrede.

Maleri af Johannes Rach og Heinrich Eegberg. Nationalmuseet.

fet i München og Ambrass, anlagt i tæt tilknytning til slottet. Det var i tre etager, hvoraf underetagen rummede en våbensamling, den mellemste det store kongelige bibliotek, og overetagen Kunstkammeret. Igen altså med klar parallel til de udenlandske fyrstehuses samlinger.

Bygningen, der var ret smal i forhold til sin længde, var længe under opførelse, og Kunstkammeret kunne ikke opstilles før i begyndelsen af 1670'erne, efter at Christian 5. var kommet til magten. Grundplanen, som er publiceret af Liisberg, demonstrerer en rational udnyttelse af de forhåndenværende kvadratmetre, og en klar opdeling af rum efter Kunstkammerets indhold. I hver ende fandtes en vindeltrappe, hvorfra man kom ud i to gavlværelser, det ene et Møntkabinet, og det andet et Perspektiv- eller Modelkam- mer. Mellem disse kamre løber i huset længde et Maleri Galleri, der indtager ca. $1 / 3$ af husets bredde. Arealet til den anden side er opdelt i fem lige store rum:

Naturaliekabinettet, Artificialkammeret, Det Indianske Kammer, Antikvitets-kabinettet, og Heltesalen.

Kunstkammer-idealerne er således på plads allerede fra første færd. Hele Verden findes samlet under husets kobbertag: Natur og kunst, de fremmede folkeslag og oldtiden, videnskaben i modelkammeret, og slægt og familie - de fyrstelige verdensherrer - i Heltesalens voksfigurer. Ligheden med Quicchebergs model er påfaldende.

Samlingen blev inventariseret første gang i 1673 , og igen i 1690 , men disse inventarer er kun beregnet til intern brug, kortfattede beskrivelser, nærmest lister, således at skiftende kunstkammerforvaltere kan hol- 
de styr på samlingen. Et egentligt museumskatalog med kommenterende tekster og tilhørende illustrationer udkom i 1696 og igen i 1710. Museum Regium hed dette værk, der er forskelligt i sin systematiske opbygning fra Worms, men dog i den kommenterende tekst og illustrationerne ikke uden ligheder med dette. Det var beregnet for det lærde publikum i ind- og udland. Kongens og dermed landets prestige skulle udbygges.

Et nyt inventar blev igen optaget i 1737 , og den senere, store accession blev optaget i efterfølgende inventarer, men ingen af disse gav dog anledning til nye udgaver af Museum Regium. 1737-inventaret er blevet publiceret i Bente Gundestrups 2-bindsværk fra 1991, og man må inderligt håbe, at det må lykkes at udgive de efterfølgende inventarer. Det drejer sig nemlig ikke kun om skriftlige kilder, der i sig selv er af stor interesse for nærværende emne, men også om de betydelige muligheder, der er for at forbinde de skriftlige med de materielle kilder. Det danske Kunstkammer er, som nævnt, en sildefødning, men det er på den anden side i den forholdsvis enestående situation, at dets genstande er demonstrerer Bente Gundestrups bog med al ønskelig tydelighed. Vi kan på den ene side læse teksten og de enkelte indførslers formulering, der naturligvis virker pudsig på en nutid, men vi behøver ikke at nøjes med det. Tingene findes, og vi kan - med Peter den Stores ord - se og lære. Den intelligente indsats, systematiseringen og videnskabeligheden hos vore museale forgængere kan vi bedre følge og forstå, når vi ikke skal nøjes med at læse om samlingernes indhold, men også kan se på selve genstandene.

Inden vi går videre med det danske Kunstkammer skal en anden manifestation af den encyklopædiske tanke, Kunstskabet, omtales. Det var Philipp Hainhofer, Augsburger, købmand og diplomat, der for alvor bragte dette begreb ind i den datidige verden. Hans Kunstschränke havde til formål at koncentrere makrokosmos i et endnu mindre format, $\mathrm{i}$ et kabinetskab, der kunne stilles op i stuen til ejerens belæring og underholdning. Han skabte disse skabssamlinger for fyrsterne og forsøgte at sælge

Grundplan af Kunstkammeret i Kobenhavn. Efter H.C. Bering Lissberg, Kunstkammeret, Kobenhavn 1897.

Tavalergarden.

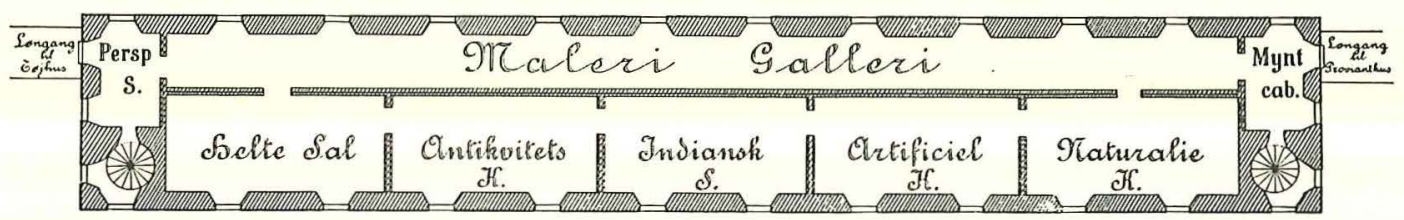

Goimuaaarden. 
12 dem, blandt andet til Christian 4., som dog afslog. Det berømteste blev skabt mellem 1625 og 1631, og blev af Augsburgs lutheranske borgerskab skænket Gustav 2. Adolph, da han med sine tropper i 1632 rykkede ind $\mathrm{i}$ byen. Det findes i dag bevaret i Uppsala.

I Danmark findes bevaret to sådanne kunstskabe, begge på Rosenborg. Det ene har tilhørt dronning Charlotte Amalie (1650-1714), det andet hendes søn, Frederik 4. (1671-1730). Indholdet af skabene er i dag spredt, og kun delvis bevaret, men det findes dog opregnet i Rosenborgs Inventarer. Charlotte Amalie var storsamler, af jordegods bl. a., men også f. eks. af porcelæn. Hun vides at have haft en samling af levende "forunderligheder", som sikkert har været betragtet i forlængelse af Kunstkammerets idé. 1687 modtog "Contrafair Jebsen" betaling for malerier af de norske drenge (Lapper?), morer, marekatte og dværge. De blev ophængt $\mathrm{i}$ et havehus. Formentlig stammer et bevaret maleri, forestillende en morpige $\mathrm{i}$ hvid kjole arm i arm med en marekat i en rød frakke, fra denne serie.

Dronningens kunstskab er et sortlakeret, japansk skab, dateret til midten af 1600 årene, stående på en udskåret, forgyldt fod fra århundredets sidste trediedel. Skabet er et importstykke, og foden, der bærer Danmarks og Hessens våben, er skåret $\mathrm{i}$ København. Således mødes vidt skilte verdener allerede i det ydre. Skabet rummede i sine 10 skuffer først og fremmest en konkyliesamling, ialt 979 stykker. Disse, der blev overført til Kunstkammeret i 1739, har ikke kunnet identificeres. Herudover var der ca. 20 andre genstande, fordelt på naturalier (heriblandt en paradisfugl, et efterstræbt samlerobjekt), artificialia (euro- pæisk), etnografica (Fjernøsten) og mønter (kinesiske). En undersøgelse af fortegnelsen over konkylierne har vist, at disse stammer fra alle egne af jordkloden. Det kan naturligvis ikke bevises, at den geografiske spredning skyldes bevidst indsamling fra dronningens side, men et lille verdensbillede har der under alle forhold været tale om. Da skabet er bevaret, kan det samtidig konstateres, at genstandene har måttet pakkes tæt, for at kunne rummes i skufferne. Ligesom for Hainhofers skabes vedkommende, har dronningen derfor måttet tage objekterne ud, for at hun kunne glæde sig over dem - og lære af dem.

Frederik 4.s kunstskab bestod i virkeligheden af en række vægskabe i Vinterstuen på Rosenborg, og samlingen er derfor betydeligt større end moderens. Den blev etableret efter at Frederik 4. i 1713 havde sejret over Holstenerne, og sammen med Peter den Store var rykket ind på Gottorp. Ved den lejlighed fik zaren som erindring den berømte store globus med til S. Petersborg, og kongen medtog en speciel del af Kunstkammeret. Resten blev overført til København som resultat af fredsslutningen i 1721 .

I de smalle vægskabe lod kongen den medbragte samling opstille, suppleret med genstande fra sine egne samlinger. Hele det spektrum, der skulle høre med til et kunstkammer, og som "efterhånden er blevet opregnet nogle gange, var repræsenteret bag de til dagligt lukkede døre. Blandt artificialierne fandtes elfenbensgenstande, drejet af Peter den Store (i dag på Rosenborg). Også billedkunsten fandtes, hvilket måske bedre end noget andet afslører hensigten, at samle hele verden. Blandt malerierne fandtes i øvrigt Breughels Fastelavnsbillede (i dag på Statens Museum for Kunst), og 
Museerne og Verdensordenen KunstKammerets opstaen og grundidé

portrætterne af farfaderens og faderens kunskammerforvaltere, Jacob Jensen Nordmand og Jan Wilckens van Verelt (i dag på Rosenborg og Frederiksborg).

I det Rosenborg, som Frederik 4. lod nyindrette $\mathrm{i}$ et vist omfang, fandtes ud over denne andre specialsamlinger. I Regaliekammeret og det tilhørende Grønne Kabinet fandtes de kostbareste ting. Hertil "havde kongen selv nøglen", som inventarerne anfører, altså med en art Skatkammer-status, direkte tilknyttet Kronen. I begyndelsen af århundredet var man i Europa begyndt at indrette rum til specialsamlinger, fortrinsvis til samlingerne af porcelæn. Under sin returrejse fra Italien i 1709 havde kongen set sådanne i Berlin, hvilket var hans inspiration til at lade sin glassamling opstille $\mathrm{i}$ det kabinet på Rosenborg, der stadig findes. Han planlagde også et porcelænskabinet, men det blev aldrig færdigt.

Det interessanteste ved verdensbilledet bag Vinterstuens døre er, at kongen - foruden sit officielle Kunstkammer - også ønskede sig et privat. Han kunne jo have begrænset sig til specialsamlingerne og ladet det øvrige indgå i Kunstkammeret, således som det faktisk skete i 1747-49.

Herefter kan vi fortsætte, hvor vi slap. Indsamlingerne til Kunstkammeret fortsatte støt gennem hele det 18. århndrede, men rammerne fulgte ikke med. Og så gik det, som det går for ethvert museum i den situation. Publikum svigter, fordi opstillingerne er uoverskuelige og usystematiske. Nyerhvervelser anbringes, hvor der er plads til det, og ikke i henhold til en klar tankegang. Internt bliver museet handlingslammet og opgivende, alt går i stå. Eneste mulige initiativ er udskillelse af dele af Samlingen.
Dette skete også med Kunstkammeret. I 1780-81 overførtes Mønt- og Medaillesamlingen til lokaler på Rosenborg, og samme sted anbragte man i 1804 Mineraliesamlingen. 1811 overførtes oldsagerne til den i 1807 oprettede Oldsagskommission, og i 1812 gik portrætgalleriet til Frederiksborg for at blive forenet med den Hjelmstierne-Rosencrone'ske portrætsamling.

Det var dog langt fra tilstrækkeligt. Tiden var løbet fra Kunstkammeret, både som praktisk museum, men også som teoretisk foreteelse. Polyhistorikerens tid var forbi, og specialisten havde holdt sit indtog. Der var ikke mere behov for det altoverskuende museum. En ny videnskabelighed krævede specialmuseer, og, når man tænker på Kunstkammerets oprindelige plan og sammensætning, var det jo i virkeligheden det, det var: en række specialmuseer anbragt i rum ved siden af hinanden.

Det var udefra kommende kræfter som måtte til for at løse problemet. Initiativet var overhofmarskalk A.W. Hauchs, rigets øverste embedsmand, som ved siden af $\sin$ militære og embedsmandsmæssige baggrund havde en naturvidenskabelig uddannelse. Allerede i 1810 havde han givet kunstkammerforvalter I.C.Spengler ordre til at gennemføre en nyt inventarium på grundlag af en ny systematisk gruppering af museet. Spenglers passive, men massive modstand er imponerende, men også en tydelig demonstration af den handlingslammelse, der prægede Kunstkammeret. Museumsfolk, der har været i en tilsvarende situation, vil kunne genkende Spenglers argumenter: De dårlige tider forringer besøgstallet, indtægterne er svigtende, hvorfor medhjælp ikke kan antages. Spengler ønsker i hvert fald personligt løn- 
14 tillæg. Faktisk lykkedes det Spengler at forsinke planerne i ca. 10 år, men Hauch holdt fast. I løbet af 1820 'rne blev hele samlingen nyregistreret efter en ny udarbejdet systematik, som det i sig selv havde voldt mange kvaler at nå frem til. Hauchs samlede plan er imponerende, mest fordi den er så radikal. Han agtede at nedlægge Kunstkammeret, hverken mere eller mindre. Men ikke for at afskaffe landets museumsvæsen, tværtimod for at oprette en række nye, selvstændige specialmuseer.

I virkeligheden er opløsningen af Kunstkammeret den bedste illustration til dettes encyklopædiske og altomfattende karakter. Alle de store statslige specialmuseer, som vi kender dem i dag, har sit udspring $\mathrm{i}$ og sine gamle kernesamlinger fra Kunstkammeret. Det gælder Statens Museum for Kunst og Kobberstiksamlingen, Antiksamlingen og Etnografisk Samling, samt Mønt- og Medaillesamlingen på National-museet. Det gælder de naturvidenskabelige museer, Botanisk Museum, såvel som Geologisk og Zoologisk Museum. Bortset fra, hvad der i 1824 overgik til Rosenborg, blev Artificialkammeret, altså kunstindustrien, i første omgang overført til museet i Dronningens Tværgade, der, set med historiens øjne kom til at fungere som en art interimsmuseum, som også rummede andre af de ovennævnte samlinger. Dette blev nedlagt i 1867, og artificialia blev fordelt mellem Oldnordisk Museum (det senere Nationalmuseum) og Rosenborg, der var blevet museum i 1833 som vort første interiørmuseum.

Hauch havde grund til at være stolt over sin indsats, hvilket han da heller ikke lagde skjul på, da han i 1833 indgav en forestilling til kongen om indretning af Rosenborg til museum. "Kun ved Deres Majestæets huldrige Beskyttelse for Kunster og Videnskaber," skrev han i det sprog, man benyttede over for sin enevældige konge, "er det kundet lykkes mig, at bringe de kongelige Samlinger, der allernaadigst ere henlagte under mit Overtilsyn, i en saadan Orden, at de kunne vare til Nytte for Kunstnere og Videnskabsdyrkere, samt ved deres hensigtsmassige, ziirlige Fremstilling regnes blandt Fadrene-landets Prydelser og Severdigheder."

Det var en ny museumsorden, som så dagens lys med Hauchs initiativ, men det helt overordnede princip var i virkeligheden uændret fra de første Kunstkamre. De skulle tjene til uddannelse og opdragelse, og de skulle være fædrelandet til ære.

Det må vel siges fortsat at være ethvert museums opgave, selvom det sidste led kun indirekte finder udtryk i loven om vor nutids udbyggede museumsvæsen. Her står der i formålsparagraffen kun, at loven skal sikre Danmarks kulturarv og fremme museernes virke og samarbejde. Søger man en begrundelse for dette formål, ville man vel i dag udtrykke det med ord som sikring af dansk identitet og Danmarks rolle som kulturnation. Grundtanken ville være den samme som Kunstkammerets.

\section{SUMMARY}

\section{The Museums and the Order of the Universe}

It is the aim of this paper to underline the similarities between modern museums and the comprehensive 'Kunstkammers' of former days. There is a tendency to overlook the rationale behind the 'Kunstkammers' and to consider them merely as haphazard collections of curiosities. 
Muserene og Verdensordenen. Kunstikammerets opstäen og GRUNDidé

The paper first describes the earliest 'Kunstkammers' from those in Vienna (1553; which Rudolph II removed to Prague), Dresden (1560), and Munich (1565) to the one in Innsbruck (1573). Two early treatises on the ordering of princely collections are mentioned - Samuel Quiccheberg (1565) and Gabriel Kaltemarckt (1587).

The contents of these 'Kunstkammers' vary according to their owners' tastes, but basically they have the same aim: to be comprehensive and encyclopaedic, to be a microcosm of the whole world gathered under one roof. Furthermore they were created for the glory of prince and country, while at the same time having an educational purpose. This latter aim was specifically mentioned by Peter the Great on the opening of his Kunstkammer in S. Petersburg in 1714. "I want people to look and learn", he declared.

Next the development in Denmark is presented, starting with the Turning Cabinets. Christian III (reigned 1534-1559) had such a cabinet and his own private turner - who was probably also his teacher. The records mention in 1568 that Fredrik II's turning cabinet or 'Wunderkammer' was adjacent to the king's bedchamber in Kronborg Castle in Elsinore. Christian IV (1588-1648), who also worked a lathe, seems to have been a collector of the old school, whereas his oldest son, the hereditary prince, who died before his father, was a more methodical collector, who seems to have been the owner of the unfortunately unknown contents of a 'Kunstkammer' in Frederiksborg Castle.

The Royal Danish 'Kunstkammer' is a late example of the European 'Kunstkammers' because of king Christian's lack of interest and the length of his reign. It was his son, Frederik III (1648-1670) who finally established it in 1650 . His strong personal interest can clearly be seen through his many acquisitions in the early years, not least the important addition of Ole Worm's 'Kunstkammer' in 1654.

In 1665 the foundations were laid for an independent building adjacent to Copenhagen Castle. The three-storeyed building, which was finished in the 1670 's contained an armoury below, the Royal
Library on the middle floor, and the 'Kunstkammer' at the top.

Today there is not only the documentary evidence of the first systematic inventory (published by Bente Gundestrup in 1991) but, because of their unusually extensive preservation, there are the collections themselves. This presents us with the rare opportunity to compare the written sources with the material objects. The items themselves are better evidence to the rationale behind the collections than the often confusing, to the modern mind sometimes merely amusing, texts.

Two 'Kunstschränke', both today at Rosenborg, are then described. Both demonstrate quite clearly the principle of the 'Kunstkammer': to have all aspects of nature and man's activities represented in a microcosm.

The paper then returns to the 'Kunstkammer'. The various inventories $(1673,1690,1737,1775,1809)$ reveal not only a growing collection, but also, since the location remained unchanged, the fate of all museums under identical conditions: showcases and rooms become overcrowded, the idea of the initial systematic exhibition is lost and the public becomes confused and bored.

Transferring the coin collections, the minerals, the antiquities, and the portraits to other museums did not suffice - quite apart from the fact that the 'Kunstkammer' was totally outdated, both as a practical museum as well as a concept. The Specialist had supplanted the Polyhistor; the specialised museum the encyclopaedic one.

The driving force in this development was an outsider, the Lord Marshall, A.W.Hauch. It took him ten years to overcome the conservatism of the museum people. But finally, during the 1820 's, the 'Kunstkammer' was dissolved, and a new museum organisation was created. Perhaps the all-embracing character of the 'Kunstkammer' is best demonstrated by the fact that all the major state museums - e g the Art Gallery, the Print Room, the Antique and Coins Collections, the Botanical, the Geological and the Zoological Museums - have one common basic source: the 'Kunstkammer'. 
16 The paper concludes with the close relationship between the purpose of the modern museum and of the 'Kunstkammer'. Both demonstrate to society the cultural identity of a nation, and intend to educate the specialist as well as the general public.

Mogens Bencard er mag.art $i$ kunsthistorie, 1961-77 antikvar ved Den antikvariske Samling $i$ Ribe, 1977-80 prosjektleder for Sydjysk Universitetscenter, Esbjerg. Fra 1980 direktor for De Danske Kongers Kronologiske Samling på Rosenborg og Amalienborg (Adr: De Danske Kongers Kronologiske Samling på Rosenborg, Øster Voldgade 4A, DK-1350 Kobenhavn K).

\section{NOTER}

1. De to guldhorn fra 500-årene blev fundet ved Møgeltønder i Sønderjylland, det første i 1639 og det andet i 1734. De endte begge i Det Kongelige Kunstkammer, hvorfra de blev stjålet og omsmeltet i 1802. Tabet gav digteren Adam Oehlenschläger anledning til at skrive det store nationalromantiske smertedigt: Guldhornene. Rollen som nationalmonument fik det første guldhorn umiddelbart efter fundet.

\section{LITTERATUR}

O. Andrup: Rosenborg gennem hundrede Aar. Hft.1. København 1933. (Et efterfølgende hefte foreligger i korrekturtryk. F. eks. på Museologisk Bibliotek)

J. Bepler (ed): Barocke Sammellust. Wolfenbüttel 1988.

M. Bencard: Dronning Charlotte Amalies Kunstskab. Neptuns Kabinett, Lund 1985.

M. Bencard: De Danske Kongers kronologiske Samling på Rosenborg. Dansk tidsskrift for museumsformid ling, 9, 1989. Også trykt i Valör.Konstvetenskapliga Studier. Nr. 3, Uppsala 1992.

M. Bencard: The Glass Cabinet at Rosenborg Palace. Journal of the History of Collections, vol. 3, no. 1, Oxford 1991.

M. Bencard: Den forste guldhornsfejde. Fortid og

Nutid, 3, 1991.
M. Bencard: Eine private firstliche Kunstkammer: Rosenborg 1718/Gottorf 1694. Bidrag til symposiet "Macrocosmos in Microcosmo - Die Welt in der Stube", Berlin 1990 (i trykken).

E.Bergvelt, R. Kistemaker (ed.): De wereld binnen handbereik, I-II. Amsterdam 1992.

H.C.Bering Liisberg: Kunstkammeret. København 1897.

B. Gundestrup: Det kongelige danske Kunstkammer 1737. København 1991.

B. Gutfleisch og J. Menzhausen: 'How a Kunstkammer should be formed'. Gabriel Kaltemarckt's advice to Christian I of Saxony on the formation of an art col lection, 1587. Journal of the History of Collections, vol. 1, no. 1, Oxford 1989.

J. Hein: Das Grüne Kabinett im Schloss Rosenborg Schatzkammer oder Raritäten-Kabinett? Bidrag til symposiet "Macrocosmos in Microcosmo - Die Welt in der Stube", Berlin 1990 (i trykken).

O. Impey og A. MacGregor (ed): The Origins of Museums. Oxford 1985.

D.Murray: Museums, their History and their Use, I-III. Glasgow 1904.

C. Riebesell: Die Sammlung des Kardinal Allessandro Farnese. Weinheim 1989.

H.D.Schepelern: Museum Wormianum. Aarhus 1971.

J. Schlosser: Kunst-und Wunderkammern, 2. udg. Braunschweig 1978.

L. Seelig: Die Münchener Kunstkammer, Jahrb. d. Bayerischen Denkmalpflege, bd. 40, München/ Berlin 1989. 